
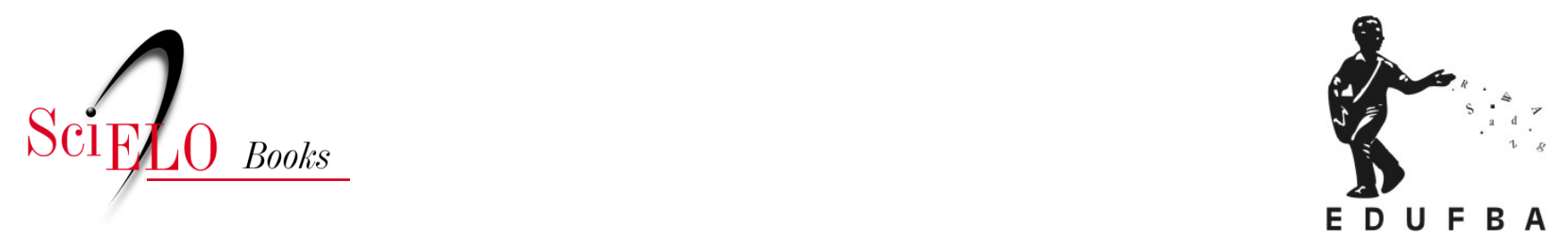

Parte III - Gênero e Cosmopolitismo

\title{
12. Marielle, presente! um luto político e uma reconfiguração da política nacional - a necessária articulação de um pensamento liberal brasileiro que incorpore demandas sociais e de inclusão
}

\author{
Heloisa Pait
}

Renata Nagamine

\section{SciELO Books / SciELO Livros / SciELO Libros}

PAIT, H., and NAGAMINE, R. Marielle, presente! um luto político e uma reconfiguração da política nacional - a necessária articulação de um pensamento liberal brasileiro que incorpore demandas sociais e de inclusão. In: VITALE, D., and NAGAMINEM R., eds. Gênero, direito e relações internacionais: debates de um campo em construção [online]. Salvador: EDUFBA, 2018, pp. 324-344. ISBN: 978-85-232-1863-8. https://doi.org/10.7476/9788523218638.0013.

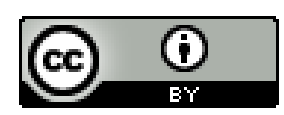

All the contents of this work, except where otherwise noted, is licensed under a Creative Commons Attribution $\underline{4.0 \text { International license. }}$

Todo o conteúdo deste trabalho, exceto quando houver ressalva, é publicado sob a licença $\underline{\text { Creative Commons }}$ Atribição 4.0. 
12

\section{MARIELLE, PRESENTE!}

Um luto político e

uma reconfiguração

da política nacional -

a necessária articulação

de um pensamento liberal

brasileiro que incorpore

demandas sociais e de

inclusão

Heloisa Pait

Renata Nagamine 


\section{Um evento simbólico}

Neste artigo analisamos o significado nacional dos protestos em repúdio ao assassinato de Marielle Franco, vereadora em primeiro mandato pela cidade do Rio de Janeiro, ocorrido em 2018 quando ela saía de um encontro com ativistas negras, parte das atividades de seu mandato. Refletimos sobre o luto por sua morte, os protestos a favor das investigações e as manifestações nas redes sociais em apoio ou contrárias a estes protestos. Para isso, usamos a ideia de Clifford Geertz (1973) sobre fenômenos culturais, sinteticamente a de que eles dizem algo sobre a sociedade para ela mesma, ou seja, são locais simbólicos de reflexão social os quais cabe ao analista interpretar. Também usamos as ideias de Elihu Katz (DAYAN; KATZ, 1994) sobre eventos mediáticos com forte caráter ritualístico, ainda que no caso analisado não tenha havido uma solenidade televisionada, mas protestos organizados de modo independente, coincidindo com datas de luto.

O assassinato foi extensamente coberto pela imprensa, em suas várias dimensões, incluindo os protestos de rua e as demandas pelo esclarecimento do crime: Marielle era uma figura local da política carioca, mas encaminhava-se para se tornar uma figura nacional por seu carisma e capacidade de articulação. Houve grande repercussão internacional, ainda que esta não tenha, de modo geral, muita ressonância no debate nacional. Várias cidades tiveram protestos, concentrados na cidade da vereadora, o Rio de Janeiro, onde ela morava, havia estudado e feito pós-graduação, e onde havia começado seu ativismo e trabalho na câmara dos vereadores como assessora parlamentar. Uma das autoras deste artigo participou de um protesto em São Paulo que marcou os sete dias de sua morte e a outra acompanhou os acontecimento a partir de uma cosmopolita cidade australiana. O significado destes protestos não é unívoco, dado o tamanho e a pluralidade da sociedade brasileira e particularmente a polarização política que tomou conta do país desde, no mínimo, as eleições de 2014. Neste artigo, exploramos algumas possíveis interpretações dos protestos e oferecemos a nossa própria, que leva em conta a estrutura política nacional mais perene. De modo muito sintético, sustentamos que a morte 
de Marielle Franco desencadeou uma guinada no conturbado debate político brasileiro dos últimos anos. Reconhecemos a importância de sua atividade pela luta de minorias e o caráter identitário das manifestações em repúdio ao seu assassinato, mas nossa interpretação vê esta luta identitária como nó político em que se entrelaçam questões mais amplas, ligadas ao próprio consenso democrático nacional.

O artigo aborda esse marcante fato político a partir de várias perspectivas. Trazemos inicialmente uma narrativa do assassinato de Marielle, dos protestos que se seguiram e das reações aos protestos, mostrando sua relevância para o quadro político mais geral nacional. Recuperamos a seguir um momento histórico relevante para compreender o papel do liberalismo no Brasil e suas dificuldades para se consolidar como uma voz possante na cacofonia da política nacional. Entretanto, o assassinato de Marielle também tem dimensões que vão além da política brasileira. Para trazer este importante contexto, resgatamos o estado atual do pensamento liberal e os desafios que encontra no plano das ideias e da prática, particularmente relevantes hoje quando parece imprensado entre correntes a ele hostis. Tal reflexão será relevante pois as interpretações da morte de Marielle vão expressar distintas visões do papel do indivíduo na sociedade e da convivência entre semelhantes, ou seja, as manifesta ções serão um local de contestação em torno de valores liberais e também democráticos. Complementamos essa dimensão internacional inserindo os protestos de repúdio à morte de Marielle Franco dentro do debate internacional e da luta pelos direitos humanos.

Buscamos assim refletir, a partir deste evento traumático da vida política brasileira, sobre o lugar do indivíduo e o futuro do pensamento liberal nesse momento de encruzilhada no Brasil e no mundo. A surpreendente conclusão a que chegamos, ao final, é que Marielle é reduzida a uma vítima a mais pelos extremos do espectro político nacional, tanto à direita como à esquerda, enquanto aqueles mais próximos do pensamento liberal conseguem enxergar na vereadora um sujeito autônomo que é parte atuante de um sistema político representativo. Resgatar sua vida enquanto sujeito autônomo passa a ser um dever acadêmico mas também ético e político. 


\section{O fim de uma aliança}

Fomos descobrindo aos poucos a vida de Marielle Franco, a vereadora de sorriso iluminado pela cidade do Rio de Janeiro. Uma amiga nos disse que seus colegas da Universidade Federal Fluminense (UFF), onde a vereadora fez mestrado, a conheceram pessoalmente. Um site judaico progressista contou que ela compartilhava da preocupação de seu companheiro de partido, Jean Wyllys, do Partido Socialismo e Liberdade (PSOL), com o antissemitismo da esquerda. Vimos sua família e ouvimos sua filha falar na TV, ainda chocada mas confiante que o crime seria solucionado, e uma identificação mais humana foi se estabelecendo entre nós e esta mulher que lamentamos não ter conhecido. Quando a mãe de uma de nós faleceu, o rabino disse: "Pense como ela viveu, e não como morreu." Ele repetia a frase de tanto em tanto para uma família atordoada, como esteve a família da Marielle, que tem inscrito sua vida na história política de nosso país com homenagens, depoimentos e atividades que honram seus valores e ações. Mas foi através do assassinato que a maior parte de nós conheceu Marielle, então é inescapável falar do que ele significou para todos nós, naquele momento político nacional.

Desde a eleição de 2014, com a tomada de consciência de que o país rumava para uma situação econômica insustentável, tivemos uma desconfortável aliança entre social-democratas e conservadores, herdeiros políticos dos antigos Partido Social Democrático (PSD) e União Democrática Nacional (UDN), contra o estatismo então no poder. Expliquemos. O PSD era o partido do mineiro Juscelino Kubitschek de Oliveira, comprometido com a democracia e com o desenvolvimento. Teve seu mandato presidencial ameaçado por golpes militares e era o candidato às eleições de 1965, que nunca aconteceram. A UDN, de Lacerda Franco e Jânio Quadros, era o partido conservador nos costumes, mas liberal na economia. Já o Partido Trabalhista Brasileiro (PTB), de Leonel Brizola e João Goulart, idealizado por Getúlio Vargas, representava o estatismo, um pouco mais ou um pouco menos autoritário, mas centralista certamente. Quando olhamos o quadro político atual, multipartidário, fica difícil ver alguma coerência 
nas alianças e nas visões de mundo de cada agremiação; entretanto, ele se aclara quando o olhamos através destas siglas, PSD, UDN e PTB.

Essa digressão é necessária porque nossa tese é que a morte de Marielle desencadeou um rearranjo nacional expressivo e ainda não resolvido nesse quebra-cabeças, que é partidário, mas também de valores e visões de mundo e de país. O PSD, com sua ênfase democrática, desenvolvimentista e progressista, seria um precursor do Partido da Social Democracia Brasileira (PSDB) de Fernando Henrique Cardoso, com sua aposta internacional, que não se descuida, porém, do desenvolvimento nacional. É o partido que mais se assemelha ao Partido Democrata americano ou aos partidos social-democratas europeus do passado recente. O Partido dos Trabalhadores (PT), com sua base sólida dentro do próprio Estado, ainda que hoje esgarçada, e sua relação ambígua com relação aos valores liberais e democráticos, como a liberdade de expressão, pode ser considerado um herdeiro do PTB, apesar de seu rechaço explícito a essa agremiação. As políticas públicas patrimonialistas que implementou no governo reforçam esse elo. A direita nacional ficou órfã de representação partidária com a derrocada da ditadura e a conversão dos partidos de sua base, o Partido Democrático Social (PDS) e o Partido da Frente Liberal (PFL), em siglas indistinguíveis de uma massa de partidos irrelevantes isoladamente, tanto numérica quanto simbolicamente. Os atuais Partido Progressista Nacional (PP) e Democratas (DEM) não representam o pensamento conservador nacional, tendo o primeiro se aliado a governos de esquerda e o segundo nunca conseguido se firmar como partido independente. A UDN, uma força política de peso que foi parar na Aliança Renovadora Nacional (Arena) durante o regime militar, sumiu como força simbólica relevante depois da redemocratização.

Voltando ao presente, podemos dizer que tivemos, entre a eleição de 2014 e a votação do impeachment de Dilma Rousseff, uma aliança incômoda do campo democrático e progressista, tributário do PSD, com o difuso campo liberal tradicional, tributário da UDN, que abarcava desde Ronaldo Caiado a Aloysio Nunes Ferreira. Quem participou das manifestações antigovernamentais de 2015 e 2016 sabe que era muitas vezes difícil estar ao lado dos monarquistas, da TFP (Tradição, Família e Propriedade), uma 
antiga organização de ultra-direita, e de novos grupos de direita, como o Revoltados Online. Alguns antigovernistas expressavam seu desacordo ao passar por eles, com vaias e palavras pouco amistosas. Tinha-se vontade de voltar no tempo, para os comícios onde cantavam Chico Buarque e Fafá de Belém e subiam no palanque Covas e Lula, Montoro e Fernando Henrique. Estávamos, nós que acreditamos no valor da vida humana e defendemos o direito reprodutivo, que vimos nossas mães quebrando barreiras no trabalho e ousando na vida privada, que testemunhamos nossos amigos afirmando, com dificuldade mas alegria, suas orientações sexuais, estávamos marchando ao lado dos ultraconservadores e da direita. Essa jornada comum pelo impeachment parecia necessária a uns e outros, mas não era confortável. Era uma aliança que se mantinha em torno de bandeiras comuns anti-corrupção, anti-estatistas e, agora fica mais claro, anti-PT.

Essa aliança provisória teve um fim abrupto com a morte de Marielle Franco. Ficou claro para seus membros que eles compartilhavam alguns objetivos, mas tinham visões de mundo díspares. Isso não foi de modo algum responsabilidade de Marielle, uma pessoa, pelo quelemos naimprensa, que buscava agregar pessoas e por isso era bem quista por familiares de policiais abatidos por essa violência terrível da nossa cidade maravilhosa. Como esse divórcio ocorreu? As manifestações a favor de investigações e em homenagem a Marielle foram, sim, políticas, duras e recriminatórias. Diziam: “Olhem, vocês do golpe de 2016, olhem isso onde deu!” Mas também foram sentidas, humanas, dignas e pacíficas. Paradoxalmente, não foi a dureza e a politização que incomodaram tanto os assim chamados "coxinhas", produto da referida aliança: foi o fato de que o protesto era absolutamente necessário, legítimo, correto, irrepreensível. Afinal, o que é mais valioso que a vida humana? Como condenar a indignação de mulheres, negros, ativistas de esquerda e jovens vendo um dos seus ser abatido sem mais nem porquê? Parte da reação aos protestos foi virulenta, levantando toda sorte de calúnias sobre a vereadora, que depois se descobriu foram reproduzidas de modo concertado por uma das organizações políticas que emergiu nos movimentos a favor do impeachment de Dilma Rousseff. Mas parte desta reação, mesmo sem o ódio, apenas com 
um fel ressentido de quem perde o protagonismo, buscava deslegitimar o caráter político da execução, colocando-a na vala dos 60 mil assassinatos anuais no país, pedindo uma tolerância para um crime que não pode ser tolerado, pois ameaça a democracia.

Os atos em memória de Marielle Franco foram os primeiros protestos de rua chamados pela esquerda em muito tempo que se legitimavam a partir de valores comuns a todos nós: a defesa da vida, da liberdade de expressão e da democracia institucional. Foi essa legitimidade que questionou a aliança que, até aquele momento, se via como detentora monopolista da justiça. Não se tratava mais da defesa de um condenado e de trapaças; de políticas desastrosas e desvios de verba: era um protesto legítimo e ao mesmo tempo desprezado por parte da aliança pelo impeachment. Devese notar, entretanto, que os protestos foram apresentados pelos manifestantes como parte de uma luta identitária ideológica que rechaçava novas alianças, o que pode ser atribuído à polarização política atual ou à própria natureza destes movimentos identitários.

Na crítica aos protestos, houve preconceito explícito com a origem social da vereadora, como o de uma desembargadora e de um infeliz deputado. Por exemplo, insinuou-se que Marielle tinha sido assassinada por relações com o Comando Vermelho, e pelas mídias sociais circularam fotos em que uma mulher que seria ela aparecia ao lado de um chefe da organização. Mais importante que isso, para nosso argumento, foi o fel dos que entenderam a gravidade do atentado e se ressentiram de um luto e uma luta que não era mais deles. Aí fizeram acrobacias mentais admiráveis para diminuir a importância de um evento de tamanho impacto nacional e internacional. Contestaram que Marielle fosse, de fato, cria da comunidade, já que ela morava na Tijuca e seus votos vinham do Leblon, e argumentavam que não se tratava de crime político. Depois dos sommeliers de tragédia e de protesto, vieram os de funeral, dizendo quais mortes se pode chorar e como é apropriado fazê-lo. Seus questionamentos eram tanto mais absurdos quanto mais se sabia: Marielle estava, no momento da execução, saindo de um compromisso da vereança, ao final de um dia de agenda intensa, fazendo o trabalho para o qual tinha sido eleita. 
(MESQUITA, 2018) Ela tinha sido morta, portanto, como vereadora, e não no espaço doméstico, ou devido à sua condição social.

Nesse momento rompeu-se a aliança UDN e PSD, o que se expressou no quadro eleitoral de 2018, com a UDN se concentrando em torno de um novo Jânio Quadros, impoluto e carismático, e o PSD demorando a encontrar seu candidato. Mesmo com o desgaste do passado, com a cumplicidade dos partidos progressistas devido ao escândalo do Petrolão, não era mais possível estar ao lado dos que afrontam os direitos básicos que associamos à cidadania. O julgamento a respeito do funeral ajudou a romper com a aliança entre, ainda usando as siglas antigas que enquadram melhor a política brasileira do que os partidos atuais, a UDN e o PSD, sendo que esse último ficou solto, em busca de um candidato, de um líder, de um partido, de uma identidade resgatada.

Somos, e aqui obviamente nos colocamos nesse campo, a favor da liberdade e do desenvolvimento humano, temos ojeriza ao autoritarismo varguista, mas também medo do machismo e da intolerância em suas várias formas. Somos naturalmente de centro, tanto ideologicamente como na busca de uma sociedade em que caiba uma variedade de posições. É verdade que essa visão progressista desgastou-se no passado recente com o desenvolvimentismo retrógrado de alguns líderes e o Estado do Bem-Estar patriarcal de outros. O termo derrogatório “isentão”, na moda nos anos do impeachment de Dilma Rousseff, refletiu bem o cansaço com esse progressivismo hesitante, que faz privatização com dinheiro de banco público e participa de protesto da sacada de Ipanema. Mas esse desgaste conjuntural não reduz sua importância para a democracia nacional. E, a cada dia, passa a ser mais importante o resgate da social democracia no seu sentido mais profundo, o de força política que aceita de coração a democracia e vê a inclusão social como parte do mesmo projeto, e não como forma de dominação da sociedade pelo Estado.

\section{Liberalismo interrompido}

Esta não é a primeira vez na história que liberais rechaçam valores do centro moderado. Antônio Paim (1998) estudioso da história do liberalismo 
brasileiro, já havia apontado o erro dos liberais em, depois do fim da ditadura Vargas, voltar à cena política sem ideias renovadas, sem a preocupação social que liberais no mundo todo haviam incorporado após a dramática crise de 1929 e a tragédia da Segunda Guerra Mundial. Os UDNistas, entre os quais o mais conhecido é o cultíssimo Carlos Lacerda, evitavam com isso dar o braço a torcer ao abominado populismo de Vargas, mas tal recusa a incorporar a questão social, para Paim, radicaliza a UDN num anti-varguismo que desemboca no golpe de 1964. Acontece algo semelhante agora: depois de um longo período de hegemonia política desse grupo estatista, ainda que não de domínio autoritário como houve durante o Estado Novo, parece que, como no pós-guerra, quer-se voltar ao tempo e rechaçar as transformações sociais ocorridas no mundo e no Brasil. Desta vez, os UDNistas optam por deslegitimar a presença das mulheres na vida pública, que é um fato, com receio de desembocar na agenda identitária construída nas últimas décadas. Busca-se ignorar a inclusão social, que é parte da vida social liberal e democrática no mundo todo. Dito de outro modo, quis-se apagar o fato óbvio de que Marielle Franco era negra, oriunda da favela, e era também vereadora.

Houve, como dissemos, os que criticaram a pessoa de Marielle Franco, insinuando as coisas mais estapafúrdias possíveis. Esses mostraram preconceito e desumanidade. Mas houve os que quiseram que a morte dela fosse tratada como uma entre as milhares que acontecem todos os anos, sem o que chamaram "politização": apenas uma vida perdida para a violência urbana. Era como se quisessem apagar o fato de que uma mulher, negra, homossexual e vinda de uma favela tinha conseguido se tornar uma liderança política expressiva a ponto de levar a uma comoção geral. Nada teria ela a ver com John F. Kennedy ou com Juscelino Kubitschek, com Martin Luther King ou Harvey Milk, políticos importantes cujas mortes foram lamentadas, investigadas e continuam sendo rememoradas. Marielle seria apenas uma mulher qualquer, sem cor política, sem voz própria, sem seguidores, dessas tantas que morrem atropeladas, ou espancadas, ou assaltadas, ou apenas pelo azar de estarem na linha de uma bala perdida, sozinhas ou com seus bebês na barriga. Vítimas anônimas. 
Os Lacerdas de hoje pedem à nação que esqueçam as décadas de inclusão, devida, em parte, a políticas específicas, em parte a esforços individuais, e também à própria dinâmica das sociedades onde há liberdade de escolhas, inclusive de empreender, e justiça. Lembremos que a inclusão de minorias, como política pública, entra em cena nos anos 1960, como resposta das universidades americanas para os conflitos raciais que pareciam exigir mais do que apenas direitos iguais. (STULBERG; CHEN, 2008) Concordando ou não com tais políticas, é fato que elas chegam ao Brasil, com atraso, e seria legítimo questionar se foram aqui aplicadas de modo produtivo ou se foram utilizadas como instrumento de cooptação para um projeto político que nada tinha de igualitário. O que não se pode negar é que a sociedade brasileira é hoje mais inclusiva que ontem, com negros e mulheres ocupando posições de destaque nos negócios, na ciência e nos meios de comunicação. O maior significado da crítica aos protestos contra o assassinato de Marielle é, portanto, a negação de todo o processo de inclusão na sociedade brasileira.

Não se trata de uma volta conservadora ao tempo em que estruturas hierárquicas de classe, gênero, raça e orientação sexual permaneciam incontestadas, mas sim de uma relativização dos valores liberais, que teve repercussões políticas importantes. O retorno a valores tradicionais exigiria o discurso de proteção a Marielle e outras mulheres que andam nas ruas das grandes cidades brasileiras, o que não seria de todo indesejada. Não se tratava tampouco de uma asserção de valores liberais clássicos, o que exigiria juntar-se aos que pedem investigações céleres e proteção efetiva aos representantes legislativos, da qual depende a democracia nacional. Talvez o resultado tenha sido o reforço do discurso reacionário sobre gênero; mas pode ter tido mais chance o reforço de nosso arraigado preconceito de classe. O principal efeito dos esforços de deslegitimação de Marielle como atriz política e, por tabela, de toda a história de inclusão das últimas décadas não é direto: é um indesejável cisma entre liberais e progressistas, com os UDNistas ressurgindo no espectro político não só de forma autônoma, o que não seria mal de todo, mas se inclinando decididamente à direita. Ou seja, podia-se ter a ilusão de que essa UDN permanecia como um apêndice do PSD durante os anos FHC e os anos de 
liderança tucana na oposição. Agora fica claro que esse pensamento político apenas não tinha a representação devida que agora busca. Nunca é demais lembrar que no passado esse divórcio deu no golpe de 1964.

A UDN que no passado aninhou-se na polarização da Guerra Fria hoje busca valores de uma direita radical que se articula globalmente e traz uma ameaça real para a democracia e desconhecida das atuais gerações. Conclamamos portanto à busca da conciliação e alargamento de alianças, com reconhecimento da inclusão social e respeito à esfera privada, também em suas expressões conservadoras. Essa proposição se justifica porque é preciso ter em mente que a nova direita não é conservadora: ela é revolucionária e propõe a transformação militante de valores na esfera pública, o que é perigoso para a liberdade individual. Os progressistas, agora, devem voltar a buscar o meio-termo, as posições conciliatórias, a moderação e o alargamento das alianças. Não é possível lutar ombro a ombro com quem acredita que a vida de um ser humano vale pouco, e fica difícil fazê-lo com quem está disposto a desvalorizá-la por conveniências políticas. Se é verdade que reduzir a morte de Marielle a uma questão de gênero ou raça é inadequado, negar que foi uma mulher que morreu enquanto fazia sua voz se ouvir - como fizeram tantas de nós nessas últimas décadas - é um completo absurdo. Liberais de fato reconhecem a estupenda história global de inclusão das últimas décadas, ao invés de, como no pós-guerra, voltarem seus relógios para trás em busca da restauração de ordens desafiadas e ao lado de utopias regressivas. Homens de verdade estão se perguntando: que cidades são essas que construímos que não oferecem proteção mínima, nem mesmo às mulheres? Homens e mulheres de verdade olham os fatos e buscam compreender qual seu papel diante deles. A morte de Marielle, ainda não elucidada, recoloca-nos, a todos nós, essa pergunta: qual nosso papel diante do Brasil de hoje? É nesse sentido que dizemos, Marielle, presente!

Essa nossa militância, entretanto, não implica ignorar os tremendos obstáculos à construção de um novo liberalismo brasileiro que vêm tanto da direita quanto da esquerda. Como dissemos, as reações aos protestos pela morte de Marielle foram amplificados, no diálogo digital, por ativistas pagos e de modo concertado. (CARIELLO; GRILLO, 2018) No Brasil 
e no mundo, é impossível ignorar os desafios ao diálogo democrático colocados por meios de comunicação que, duas décadas atrás, víamos como a cristalização do ideal iluminista do conhecimento livre e de um humanismo sem fronteiras. No caso de Marielle, as reações a seu assassinato evidenciaram o potencial desses meios de criar ficções que pareciam ganhar densidade à medida que eram compartilhadas por mídias sociais, passando a concorrer com os fatos, os fatos reais, conforme circulavam. Em lugar de aumentar a simetria na esfera pública, o uso desses meios de certo modo a deformava; em lugar de constituir o humano em interações subjetivas, como postulou Hannah Arendt (2004), essas interações se constituíam em esforços desumanizadores. Reconheçamos, também, que os desafios a alianças políticas mais profícuas não vem apenas daquela recusa UDNista em olhar para novos fenômenos políticos. É também verdade que a trajetória de Marielle foi vista, em particular pela esquerda universitária, como produto e símbolo das políticas de inclusão dos últimos governos, ou seja, como triunfo de uma certa visão de mundo. Se esse ambiente universitário foi onde ela se formou e progrediu, isso por si só não responde, entretanto, por sua constituição como pessoa e líder. Nesse ponto, a teoria política pode nos ajudar a pensar a relação entre identidades e individualidade.

A relação entre as identidades e o campo político tem sido um objeto preferencial do debate feminista desde finais dos anos 1980 e 90, quando se colocou nesses termos na academia norte-americana. Nesse debate, Fraser representa um esforço de síntese (CYFER, 2009) entre posições modernas, que negligenciariam a formação da subjetividade, e pós-modernas, que as enfocariam, mas, paradoxalmente, negligenciariam a dimensão intersubjetiva desse processo. Engajada nessa troca de ideias ao longo dos anos 1990, Fraser (1996) aborda as chamadas questões identitárias e as materiais, ou distributivas, como problemas de justiça que poderiam ser remediados pelo reconhecimento ou pela redistribuição, mas que eram primordialmente relacionados com a paridade. Elas eram, em síntese, uma questão de igual status nas interações sociais. Não remetiam a demandas pela valorização da diferença, nem aventavam qualquer tipo de reformismo social ou das mentalidades, e isso não porque a dimensão 
psíquica, da autoestima, não tivesse importância, mas porque ela não podia ser observada na análise social e daria abertura a projetos autoritários. Comprimida entre as visões mais ideológicas que se apropriam da figura de Marielle, fica, então, essa que propomos aqui, de um indivíduo autônomo e uma representante eleita por um eleitorado construído politicamente. Se essa multiplicidade de percepções sobre sua jornada fez de seu assassinato um marco político, também é verdade que estas percepções ainda se chocam em outras oportunidades, sem que saibamos como avançar a que mais oferece possibilidades para um diálogo de ampla envergadura.

Em outras palavras, os desafios para a construção de um discurso liberal, democrático e progressista, no Brasil, não são poucos. Marielle sem dúvida não pode ser esquecida, mesmo diante de tantos dramas nacionais que se sucedem a cada dia. Mas qual Marielle? Aquela que apenas reflete uma visão de mundo identitária, gestada na universidade? A mulher que se meteu onde não devia? Ou a representante eleita, democraticamente, morta no exercício de suas funções parlamentares, que são a de ouvir a população e buscar soluções para seus problemas?

\section{Facetas do liberalismo}

Olhemos agora esse evento trágico numa perspectiva mais ampla, considerando desafios locais e globais com os quais liberais de todo o mundo têm se deparado. O assassinato da vereadora Marielle Franco, em 14 de março de 2018, nos convoca a pensar os limites, as possibilidades e a importância do liberalismo em uma sociedade com uma história de períodos autoritários intermitentes e com demandas sociais e de inclusão prementes, como é o caso da sociedade brasileira.

Não somos as únicas no campo liberal a atender a esse chamado da consciência. Há uma profícua e recente literatura sobre o tema, que compreende desde The Once and Future Liberal, de Mark Lilla, (2017) a Como as democracias morrem, de Steven Levitsky e Daniel Ziblatt (LEVITSKY; ZIBLATT, 2018) Evocamos também o recente ensaio de Andrea Faggion 
(2018) publicado em meio às disputadas e potencialmente mais importantes eleições brasileiras desde a redemocratização.

Nele, Faggion parte da postulada neutralidade diante das escolhas individuais, que o pensamento liberal justifica como sendo uma posição natural ou necessária a assegurar a pluralidade de ideias, opiniões e ideais de boa vida, para defender que o pensamento liberal assuma uma concepção de bem. É realmente comum se argumentar que o liberalismo não encerra uma ideia de bem, mas se propõe a articular e sustentar uma configuração política que contemple múltiplos compromissos com o bom, o qual é por definição relativo: o bom é sempre bom para. (ARENDT, 1990) Esta é uma imagem que o liberalismo cultiva de si mesmo e uma postura, como dissemos, diante da pluralidade de opiniões, valores e escolhas, tomada como um dado de realidade, um fato da vida. Essa postura não implica, contudo, relativismo moral (GEERTZ, 2001), ou seja, abrir mão de distinguir o certo do errado desde uma perspectiva moral, e sim buscar compreender sem ser compreensivo, como disse Geertz. Desde a perspectiva liberal a qual nos filiamos, este esforço se justifica em função do compromisso fundamental do liberalismo com a liberdade, que, em termos políticos, encerra a forma democrática. Para liberais no sentido em que reivindicamos o termo, a ordem é um produto da liberdade regulada, isto é, de uma liberdade constituída pelo direito (KANT, 2003), que substitui a guerra de todos contra todos, entendida como qualquer situação em que a lei do mais forte se impõe como a lei da terra.

Mas, se é assim, o liberalismo não é propriamente neutro em relaçãoàs concepções de boa vida. Ele tem um compromisso com a autonomia, com a ideia de que a relação de todos com o Estado e de uns com os outros depende do compromisso com a coabitação e o consentimento individual, que se entende ser tácito para conciliá-lo com a necessidade de manter a estrutura básica em que a ação política tem lugar. Se discordamos das leis pelas quais nos obrigamos, podemos agir para alterá-las, ou seja, podemos agir politicamente, pois a liberdade de discordar, expressar dissenso e buscar apoio para as alterações propostas é assegurada. Nessa linha de argumentação, o liberalismo também estaria comprometido com a mudança social pacífica, para a qual os direitos humanos são instrumentais, 
por possibilitarem aos indivíduos desafiar leis formais, bem como costumes, tradições, crenças e práticas. No Brasil, eles foram usados, por exemplo, tanto em ações coletivas, para formular demandas por direitos civis e sociais, quanto para fundamentar decisões judiciais sobre cotas raciais, o aborto de feto anencéfalo e o reconhecimento das uniões estáveis entre pessoas do mesmo sexo como entidade familiar. Ressaltar a importância dos direitos humanos para a democracia não implica, é claro, ter uma relação acrítica com eles ou endossar usos meramente instrumentais deles, que contribuam mais para a manutenção de certa ordem das coisas do que para a transformação social. Mas o assassinato de Marielle, uma defensora intransigente dos direitos humanos, mostra seu potencial de desafiar hierarquias remanescentes, como a de gênero e racial, e propostas autocráticas. Os direitos humanos aparecem, em certas quadras políticas, como um elemento de resistência democrática, o que nos ajuda a entender os ataques que sofrem no Brasil e as disputas travadas em torno deles.

Disso temos que o papel do liberalismo em questões de justiça social não pode ser ignorado. $\mathrm{O}$ assassinato de Marielle e sua repercussão, que o constituiu em arena simbólica de conflitos, serviram como campo de batalha entre concepções distintas de direitos e exigem, assim, que repensemos o liberalismo contemporâneo, seus desafios e possibilidades, no plano conceitual e político. Tal arena simbólica estendeu-se além das fronteiras do país, com significados em parte distintos, em parte coincidentes, como trataremos a seguir.

\section{Além das fronteiras}

A morte de Marielle foi destaque fora do país, sendo noticiada por jornais de circulação global, como The Guardian, The New York Times e The Washington Post. Nos dias que antecederam e sucederam o assassinato da vereadora, discutíamos com amigos no Brasil que não sabiam se iam ou não iam aos protestos, temendo que imagens da multidão fossem usadas para fins eleitorais. Ir ou não ir a uma manifestação tinha se tornado um objeto de deliberação no país, uma questão que envolvia pensar, ponderar 
e discernir. Professoras e pesquisadoras australianas e europeias nos procuravam, consternadas, querendo saber mais. Perguntavam se conhecíamos Marielle e qual sua importância e do seu assassinato para a política brasileira. Uma professora eminente comentou com pesar sua morte em um curso sobre direitos humanos; outra tocou no assunto a caminho de uma palestra, com seriedade e inquietação.

A “intervenção militar constitucional” no Rio de Janeiro, então recentemente decretada, aparecia como um aspecto contextual importante. Marielle era uma dura crítica da medida e do que considerava ser a militarização da vida, que para ela recaía especialmente sobre as favelas. Como assessora parlamentar, ela tinha acompanhado de perto o trabalho da CPI das Milícias, no Rio de Janeiro, e como vereadora era membro do Observatório da Intervenção, que fiscalizaria a atuação das forças armadas na cidade. Fora do país, a medida não era apontada como causa do crime, mas era um elemento perturbador por si só, e o assassinato de uma vereadora tão bem votada com uma intervenção na segurança em curso e ocupando o Rio de Janeiro um lugar privilegiado no imaginário dos estrangeiros foi interpretado como um sinal da gravidade da situação política no Brasil.

Um grupo atuante de pesquisadores e professores sul-americanos da Universidade de Melbourne organizou um seminário sobre o significado do assassinato de Marielle e da prisão do presidente Lula para a democracia, ao qual compareceu uma maioria de doutorandos brasileiros e alguns estrangeiros. Sobre Marielle todos concordávamos. Compartilhávamos a percepção de que ela tinha sido morta em função de sua atuação política, de suas falas e práticas denunciando milícias e a violência policial no Rio de Janeiro. Sua morte tinha relação com seus atos e opiniões, ainda que o sentido de sua atuação política também tivesse para ela relação com a cor da sua pele, sua classe social, seu gênero, sua orientação sexual. Marielle identificava-se como mulher, negra, mãe e cria da favela da Maré (HELENA, 2018), e falava, em parte, como representante desses grupos nos espaços institucionais. Um estudioso da atuação de grupos paramilitares no Rio de Janeiro falou sobre o problema e comentou que chegou a conhecê-la. Na troca de impressões e ideias com outros debatedores e a 
audiência, a execução de ativistas de direitos humanos e a violência armada - policial ou paramilitar, ligada ao tráfico ou não - apareceram como uma questão continental, um desafio para as democracias latino-americanas.

O jornal britânico The Guardian recontou a história da vereadora, descrita como uma mulher negra, mãe solteira, moradora da favela, homossexual, inteligente e competente, que entrou para a política ao perder uma amiga morta por uma bala perdida num confronto armado entre a polícia e traficantes na Maré. Marielle, lembrou o jornal, teve contato com a política em uma igreja local, sendo a sua história nesse aspecto semelhante a uma grande parcela da esquerda latino-americana desde os anos 1960, aí incluída a brasileira. No continente de um modo geral, mas especialmente no Brasil, o movimento de direitos humanos foi ganhando forma ao longo dos 1960 e 70 sobretudo nas redes da Igreja Católica (MOYN, 2010), em que se formulou uma corrente de pensamento, a Teologia da Libertação, que enfocava mais as questões de justiça social do que os dogmas e a moralidade cristãos. Segundo o jornal, foi nessa corrente de pensamento, a Teologia da Libertação, que Marielle começou a se constituir como atriz política, e depois foi buscar educação formal, aproveitando as oportunidades que se abriram a ela: o cursinho comunitário pré-vestibular na Maré, onde conheceu Mônica Benício, sua viúva, o ingresso na PUC-Rio, com bolsa da universidade, e o mestrado na UFF.

No luto global, que pudemos acompanhar de várias formas, houve espaço para falas mais identitárias, que colocavam Marielle como uma vítima a mais da violência a que as mulheres estão submetidas, e em particular as negras ou pobres, seja no âmbito familiar ou na vida social. A essas marcas ainda se somava a de cidadã de um país do terceiro mundo, sobre determinando a opressão e o silenciamento de tais vozes. Aos olhos de quem luta pela democracia liberal num país em desenvolvimento, no entanto, tal postura se confunde com a aceitação fatalista de que a violência em certos espaços seja algo perene e que necessariamente atinja os mais desprotegidos. Marielle equipara-se deste modo a Malala Yousafzai, a estudante paquistanesa, ou a adolescente palestina Ahed Tamimi. Malala e Tamimi, porém, são vítimas de um sistema opressor ao qual não 
pertencem, enquanto Marielle pagou um preço por seu próprio sucesso como representante eleita e de futuro promissor no interior de um sistema político. Há, assim, uma perturbadora semelhança entre a visão identitária, nacional e global, e a deslegitimação conservadora que apontamos em seção anterior deste artigo: apesar da diferença em intenções e valores, ambas colocam para trás do palco a líder política de impacto Marielle Franco, reduzindo-a a uma a mais num redemoinho social no qual sua voz não contava.

As duas perspectivas ainda nos fazem perder de vista um aspecto de Marielle que sua morte nos revelou, sua habilidade em tecer alianças, que fica evidente no fato de que ela era uma crítica contundente da violência armada e da atuação da polícia carioca, mas lutava, ao mesmo tempo, pelos interesses das famílias de policiais mortos e dos próprios policiais como servidores públicos. Foram algumas dessas famílias que, quando as notícias falsas em torno de sua morte surgiram, apressaram-se em desmenti-las publicamente, de modo que as práticas de Marielle de que tivemos notícia com seu assassinato evidenciaram sua autonomia e seu olhar singular, que não abria mão nem de julgar os atos, nem de construir alianças que transbordavam as identidades com as quais ela falava de si.

Sua vida também foi contada, para além das narrativas identitárias, do modo como foi vivida entre nós: uma história de superação e de um sucesso improvável, na qual as várias identidades traziam obstáculos que Marielle de fato precisou superar e questões de justiça com as quais se engajou no esforço por tornar viável a própria vida. Listadas em sequência, não eram identidades que falavam por si. Na matéria do The Guardian, vamos nos dando conta de que elas se traduziram em dificuldades muito reais que, como Marielle insistia em mostrar, continuam intervindo no cotidiano das favelas e bairros pobres das nossas cidades. Nessa linha de pensamento, lemos manifestações de pessoas públicas em redes sociais, como a atriz Viola Davis, Hillary Clinton, o casal Obama, e de outros jornais estrangeiros que foram, além disso, inequívocas em afirmar o caráter político do crime, lembrando que Marielle tinha sido morta como uma vereadora do Rio de Janeiro e ativista de direitos humanos, ao sair de um debate com mulheres negras na Lapa. 


\section{Um luto contestado}

No luto pela morte de Marielle Franco, portanto, cruzam-se vários planos que este artigo apenas começa a desenhar. Uma vereança dedicada a buscar uma vida melhor para moradores de favelas cariocas, contra o violento poder local, é promovida por um discurso identitário gestado na cultura americana e apropriado pela academia brasileira. Discursos políticos com firmes raízes nacionais são fortalecidos e também questionados num ambiente comunicativo ainda pouco compreendido. Um liberalismo humanista global, institucional e culturalmente, vê na perda de Marielle motivo de alarme e tenta uma aglutinação que precisa levar em conta significados locais muito particulares.

O evento aqui teve uma relevância política específica, enquanto no exterior ele entrou no quadro mais geral da luta contra a discriminação, um discurso por um lado universalista, que cobra corretamente a apuração de violações aos direitos humanos, mas por outro lado paternalista, como se existisse uma cultura patriarcal e atrasada, irremediavelmente responsável por tais crimes. Tanto no exterior como no Brasil, uma interpretação mais humanista e democrática se desenha, frágil mas persistente, que insiste em ver em Marielle Franco uma mulher de verdade, com sua condição, nos dizeres de Arendt, e sua capacidade de ação. Essa visão precisa se articular de modo politicamente mais efetivo, pois tanto à esquerda quanto à direita houve tentativas de colocar Marielle como uma mera representante de um grupo difuso e subordinado.

Não são de agora, como dissemos, as dificuldades do liberalismo nacional. Sob ataque globalmente, ele exige também que reflitamos sobre seus desafios locais. No caso brasileiro, seria preciso um reexame da transição democrática e de sua aposta na inclusão social como resposta para os anos autoritários, que talvez tenha roubado dos liberais uma arena de atuação legítima e democrática. O caso brasileiro, tão envolvido em si mesmo, pode oferecer um excelente prisma para entendermos os dilemas da democracia ao redor do mundo e do papel do indivíduo em suas relações políticas com seus semelhantes. 


\section{Referências}

ARENDT, H. A condição humana. Rio de Janeiro: Forense, 2004.

ARENDT, H. Philosophy and Politics. Social Research, New York, v. 57,

n. 1, 1990.

CARIELLO, G.; GRILLO, M. Facebook tira do ar página e perfis associados à onda de fake news contra Marielle. O Globo, 2018.

CYFER, Ingrid. A tensão entre modernidade e pós-modernidade na crítica à exclusão no feminismo. Tese (Doutorado) - Faculdade de Filosofia, Letras e Ciências Humanas, Universidade de São Paulo, São Paulo, 2009.

DAYAN, D.; KATZ, E. Media Events: The Live Broadcasting of History. Cambridge: Harvard University Press, 1994.

FAGGION, A. Por um liberalismo sem neutralidade. O Estado de S. Paulo, Estado da Arte, 2018.

FRASER, N. (Ed.). Social Justice in the Age of Identity Politics:

Redistribution, Recognition, and Participation. The Tanner Lectures on Human Values. Stanford: Stanford University, 1996.

GEERTZ, C. The Interpretation of Cultures. New York: Basic Books, 1973.

GEERTZ, C. Nova luz sobre a antropologia. Rio de Janeiro: Zahar, 2001.

HELENA, L. Marielle Franco: Mulher, negra, mãe e cria da favela da maré. M de Mulher, 19 mar. 2018.

LEVITSKY, S.;ZIBLATT, D. Como as democracias morrem. Rio de Janeiro: Zahar, 2018.

LILLA, M. The Once and Future Liberal: After Identity Politics. New York: Harper, 2017.

MESQUITA, L. Os últimos momentos de Marielle Franco antes de ser morta com quatro tiros na cabeça. BBC News Brasil, 2018.

MOYN, S. The Last Utopia: Human Rights in History. Cambridge, Mass.London: The Belknap Press of Harvard University Press, 2010.

PAIM, A. História do liberalismo brasileiro. São Paulo: Editora Mandarim, 1998. 
STULBERG, L. M.; CHEN, A. S. The Forgotten Origins of Affirmative Action in College and University Admissions, 1961-1969. Working Paper 2007-001, Gerald R. Ford School of Public Policy, Ann Arbor, 2008. 